\title{
Molecular analysis of an esterase-encoding gene from a lipolytic psychrotrophic pseudomonad
}

\author{
David B. McKay, ${ }^{1}$ Michael P. Jennings, ${ }^{1}$ Elizabeth A. Godfrey, ${ }^{1}$ Ian C. MacRae, ${ }^{2}$ \\ PETER J. ROGERS ${ }^{1}$ and IFOR R. BEACHAM ${ }^{1 *}$ \\ ${ }^{1}$ Division of Science and Technology, Griffith University, Nathan, Brisbane, Queensland 4111, Australia \\ ${ }^{2}$ Department of Microbiology, The University of Queensland, Brisbane, Queensland 4072, Australia
}

(Received 25 July 1991; revised 28 October 1991; accepted 19 November 1991)

\begin{abstract}
An esterase gene (estA) from a lipolytic psychrotroph (Pseudomonas sp. LS107d2), was cloned in Escherichia coli and its nucleotide sequence was determined, revealing an ORF encoding a polypeptide of 389 amino acid residues, with a molecular mass of $42276 \mathrm{Da}$. Labelling of plasmid-encoded proteins with $\left.\right|^{35}$ S|methionine, using the maxicell procedure, gave a single polypeptide of molecular mass $42 \mathrm{kDa}$, consistent with that calculated from the ORF. Colonies of $E$. coli cells containing est $A$ produced a clear halo when grown on solid media containing tributyrin; no clearance was produced when cells were grown on media containing triolein. Extracts of cells containing est $A$ also hydrolysed water-soluble nitrophenol esters, but were unable to cleave water-insoluble substrates. The preference for water-soluble substrates indicates that the gene product is an esterase.
\end{abstract}

\section{Introduction}

The significance of psychrotrophic organisms in the spoilage of milk is widely recognized (Cousin, 1989). Milk spoilage can occur because of the accumulation of free fatty acids produced from the hydrolysis of triacylglycerides by lipases. Organisms of the genus Pseudomonas constitute the most common psychrotroph isolated from milk (Muir et al., 1979; Cousin, 1982; Deeth \& Fitzgerald, 1983). In particular, psychrotrophic pseudomonads dominate the lipolytic microflora of raw bovine milk samples which show lipolytic defects, and caprine milk samples which have been refrigerated for several days (Shelley et al., 1986; Cox \& MacRae, 1989). Pseudomonas fluorescens and Pseudomonas fragi have been identified as the most predominant lipolytic psychrotrophic species; the relative importance of these two species in lipolytic spoilage may depend on other factors such as initial cell numbers, growth rates and, in

* Author for correspondence. Tel. 78757445 ; fax 78757656

Abbreviations: BFA, butter fat agar; TBA, tributyrin agar; TOA, triolein agar.

The nucleotide sequence data reported in this paper have been submitted to GenBank and have been assigned the accession number M68491. regard to products derived from heat-treated milk, the thermostability of relevant enzymes (Griffiths, 1981; Shelley et al., 1986; Cox \& MacRae, 1989). Lipolytic spoilage is mainly due to the production of even-carbonnumber short-to-medium chain (C4 to $\mathrm{C} 12)$ fatty acids from triacylglycerides (Cousin, 1989). Because nearly all triacylglycerides are completely insoluble in water, the enzymes responsible for initial hydrolysis are, by definition, lipases since they act at an oil-water interface. It is unclear, however, whether esterases, which act only on soluble substrates, also play a part in lipolytic spoilage by hydrolysing soluble mono- and diacylglycerides. As part of a study on the individual enzymes involved in lipolytic spoilage, and the genes which encode them, we have initiated a molecular genetic analysis of strains of psychrotrophic lipolytic pseudomonads isolated from caprine milk. We describe the isolation and characterization of a gene which encodes an esterase active on tributyrin, and on artificial substrates (nitrophenol esters) with acyl chain lengths up to $\mathrm{C} 10: 0$.

\section{Methods}

Bacterial strains, plasmids and media. The Pseudomonas strain used in this study, LS107d2, was one of a number of strains isolated in a survey of proteolytic and lipolytic psychrotrophs in caprine milk (Cox \& MacRae, 1989). It derives from phenon $G$ of this study, and resembles 
Pseudomonas fluorescens. E. coli strain LE392 (supE44 supF 58 hsdR 514 galK2 galT 22 metBI trpR55 lacY 1; Sambrook et al., 1989) was the host strain used for cosmid bank construction and TG1 (supE hsd $\Delta 5$ this(lac-proAB) $\mathrm{F}^{\prime}\left[\right.$ traD36 proAB+ lacI ${ }^{q}$ lacZ $\left.\Delta \mathrm{M} 15\right]$; Sambrook et al., 1989) was used for all other genetic manipulations and for enzyme assays. The cosmid vector pHC79 (Hohn \& Collins, 1980) was used for cosmid library constructions. pHP34 (Prentki \& Krisch, 1982) and pSK (BLUESCRIPT M13+; Stratagene), were employed as cloning vectors. For general strain maintenance and recombinant DNA manipulation, LB medium (Sambrook et al., 1989) was used, either as broth, or solidified with $1.5 \%(\mathrm{w} / \mathrm{v})$ bacteriological agar. Butterfat agar (BFA), containing $0 \cdot 1 \%$ butterfat, was made according to Shelley et al. (1987). Tributyrin agar (TBA) and triolein agar (TOA) were made in the same way as BFA, except that $1 \%(\mathrm{v} / \mathrm{v})$ tributyrin or $0.1 \%$ triolein were added in place of butterfat. Where appropriate, ampicillin and tetracycline were added to final concentrations of $50 \mu \mathrm{g} \mathrm{ml}^{-1}$ and $20 \mu \mathrm{g} \mathrm{ml}^{-1}$, respectively.

Cosmid library construction and screening. Chromosomal DNA was isolated from LS107d 2 and purified on a caesium chloride gradient as described by Sambrook et al. (1989). The DNA was partially digested with Sau3A to yield high-molecular-mass fragments, and then ligated with BamHI-digested pHC79 without prior fractionation. The ligation mix was packaged, using 'Packagene' extract (Promega), transfected into LE392, and plated onto LB plates containing ampicillin. To screen for hydrolytic activity, individual recombinants were patched onto BFA or TBA plates and incubated at $30^{\circ} \mathrm{C}$ for $5-10 \mathrm{~d}$; hydrolytic activity is indicated by zones of clearing around the colonies.

Recombinant DNA techniques. Unless described in detail, all recombinant DNA methods were essentially as described by Sambrook et al. (1989).

Creating overlapping unidirectional deletions using exonuclease III and mung bean nuclease. The method was essentially as described by Henikoff (1984). The fragment to be analysed was cloned into pSK and plasmid DNA was prepared. The plasmid DNA was digested with two enzymes, one leaving a $3^{\prime}$ single stranded overhang and the other a blunt end or $5^{\prime}$ overhang. The digested DNA was then incubated at $37^{\circ} \mathrm{C}$ in a reaction mixture containing (per time point) $1 \mu \mathrm{g}$ DNA, $2.5 \mu \mathrm{l} 2 \times$ exonuclease III buffer $(100 \mathrm{~mm}$-Tris/ $\mathrm{HCl}, \mathrm{pH} 8.0,10 \mathrm{~mm}$ $\mathrm{MgCl}_{2}, 20 \mu \mathrm{g} \mathrm{ml}^{-1}$ tRNA), $0.5 \mu \mathrm{l} \beta$-mercaptoethanol, $0.2 \mu \mathrm{l}$ exonuclease III (Promega, 25 units $\mu l^{-1}$ ), in a final volume of $5 \mu \mathrm{l}$. Reaction mixture $(5 \mu \mathrm{l})$ was removed at $60 \mathrm{~s}$ intervals to tubes containing $4 \mu \mathrm{l}$ of $10 \times$ buffer ( $300 \mathrm{~mm}-\mathrm{NaOAc}, \mathrm{pH} 5 \cdot 0,500 \mathrm{~mm}-\mathrm{NaCl}$, $10 \mathrm{mM}-\mathrm{ZnCl}_{2}, 50 \%(\mathrm{v} / \mathrm{v})$ glycerol $)$ and $31 \mu \mathrm{l}$ sterile water, and placed in liquid nitrogen. The exonuclease III was then inactivated by incubation at $68^{\circ} \mathrm{C}$ for $15 \mathrm{~min}, 1 \mu \mathrm{l}$ of mung bean nuclease (Promega; 3 units $\left.\mu \mathrm{l}^{-1}\right)$ was added and the mixture was incubated at $30^{\circ} \mathrm{C}$ for $30 \mathrm{~min}$. After the incubation, $1.5 \mu \mathrm{l} \mathrm{10 \%}$ (w/v) SDS, $2 \mu \mathrm{l} 1 \mathrm{M}$-Tris/HCl $\mathrm{pH} 8.6,4 \mu \mathrm{l} 8 \mathrm{M}-\mathrm{LiCl}$ and $50 \mu \mathrm{l}$ phenol/chloroform (saturated with $10 \mathrm{~mm}$-Tris/1 mM EDTA, pH 8.0) were added, the mixture vortexed, and then centrifuged for $3 \mathrm{~min}$. The aqueous phase was extracted once with chloroform, and then ethanol-precipitated, washed, dried and resuspended in sterile distilled water. The deleted DNA samples were then ready for analysis on agarose gels, prior to ligation. The extent of deletion was determined by nucleotide sequence analysis.

Nucleotide sequence analysis. Suitable fragments were either subcloned into M13mp18 or M13mp19 (Messing, 1983) or sequenced directly from recombinant plasmids using supercoiled plasmid templates. Supercoiled template preparation was essentially as described by Kraft $e$ t al. (1988), and templates were denatured as described by Lim \& Pen (1988). Nucleotide sequence analysis was performed by the dideoxy-chain termination method using a modified T7 DNA polymerase (Tarbor \& Richardson, 1987). Sequencing reactions were electrophoresed on $6 \%(\mathrm{w} / \mathrm{v})$ denaturing polyacrylamide gels, which were cast as wedge gels with a thickness gradient of $0.2 \mathrm{~mm}$ (top) to $0.6 \mathrm{~mm}$ (bottom) (Olsson et al., 1984).

Detection of plasmid encoded protein products by maxicell analysis. Proteins encoded by cloned DNA fragments were specifically labelled with $\left[{ }^{35} S\right]$ methionine using 'maxicells', and radiolabelled proteins were analysed by denaturing PAGE (Calhoun \& Grey, 1981).

Preparation of cell-free extracts and enzyme assay. Cells containing the appropriate plasmid were grown to stationary phase in LB medium (typically $500 \mathrm{ml}$ ) containing ampicillin. Following growth, cells were harvested by centrifuging at $6000 \mathrm{~g}$ for $10 \mathrm{~min}$ and resuspending the pellet in $200 \mathrm{ml} 50 \mathrm{mM}$-Tris/ $\mathrm{HCl}$ buffer, $\mathrm{pH} 8.0$. The cells were again collected by centrifugation at $6000 \mathrm{~g}$ for $10 \mathrm{~min}$ and the pellet was resuspended in a small volume $(5-7 \mathrm{ml})$ of ice-cold $50 \mathrm{mM}-\mathrm{Tris} / \mathrm{HCl}$ buffer $\mathrm{pH} 8.0$. Each sample of washed cells was then disrupted by ultrasonication on ice, and the sonicates were centrifuged at $4{ }^{\circ} \mathrm{C}$ for $20 \mathrm{~min}$ at $10000 \mathrm{~g}$. The supernatants were assayed for enzyme activity using a method based on that of Winkler \& Stuckmann (1979). Assays were carried out by adding $100 \mu \mathrm{l}$ cell-free extract, $25 \mu \mathrm{l}$ substrate solution ( $9 \mathrm{mM}$ in isopropanol) and $975 \mu \mathrm{l}$ assay buffer $(50 \mathrm{~mm}$ $\mathrm{Na}_{2} \mathrm{HPO}_{4}, 5.75 \mathrm{~mm}$-sodium deoxycholate and $0.11 \%$ gum arabic, pH 8.0) prewarmed to $37^{\circ} \mathrm{C}$. Rates of hydrolysis of substrates by cellfree extracts were measured on an Hitachi recording spectrophotometer at $37^{\circ} \mathrm{C}$. In all cases, rates of hydrolysis of substrates by the control extracts were subtracted from sample rates; $p$-nitrophenylbutyrate and $p$-nitrophenylacetate were found to spontaneously hydrolyse at a significant rate in aqueous solution $\left(0.005 \mathrm{nmol} \mathrm{min} \mathrm{min}^{-1}\right)$. Specific activity was expressed as nmol substrate hydrolysed per minute per $\mathrm{mg}$ of protein present in the cell-free extract. Protein was estimated using a bicinchoninic assay reagent kit (Pierce).

\section{Results and Discussion}

\section{Isolation of the estA gene}

DNA from LS107d2 was used to construct a cosmid library, from which 2000 colonies were screened on BFA and TBA plates. After $10 \mathrm{~d}$ incubation, nine positive colonies were detected on TBA and none on BFA. Cosmid DNA was isolated from the most active TBA clone, pLGB1, for further analysis. The cosmid was subcloned by partial digestion with Sau3A followed by ligation with BamHI-digested pHP34. Recombinants were then patched on media containing TBA to detect active subclones. Two positive subclones, pLGB11 and pLGB12 (see Fig. 1a), were selected for further

Fig. 1. (a) Summary of cosmid bank construction and initial subcloning of the est $A$ coding region. Vector sequence, pHP34 (Prentki \& $\mathrm{K}$ risch, 1982), in the plasmid maps is represented by a thin black line. The cross-hatched line represents insert DNA. The bla gene and origin of replication are represented by arrows. (b) Summary of subcloning to define the est $A$ coding region. Vector sequences, pHP34 and pSK $(\mathrm{M} 13+)$, in the plasmid maps are represented by thin and thick black lines, respectively. The cross hatched line represents insert DNA. The extent and orientation of the est $A$ coding sequence is represented by an arrow. 
(a)

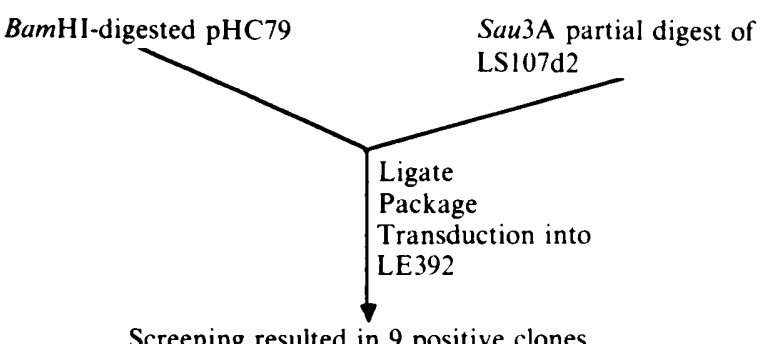

Screening resulted in 9 positive clones.

One of these, pLGB1, was

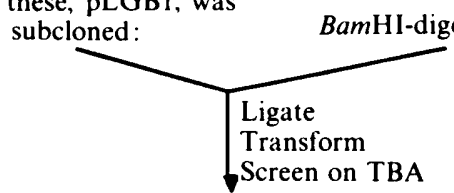

Two positive clones, pLGBI1 and pLGB12, chosen for analysis.
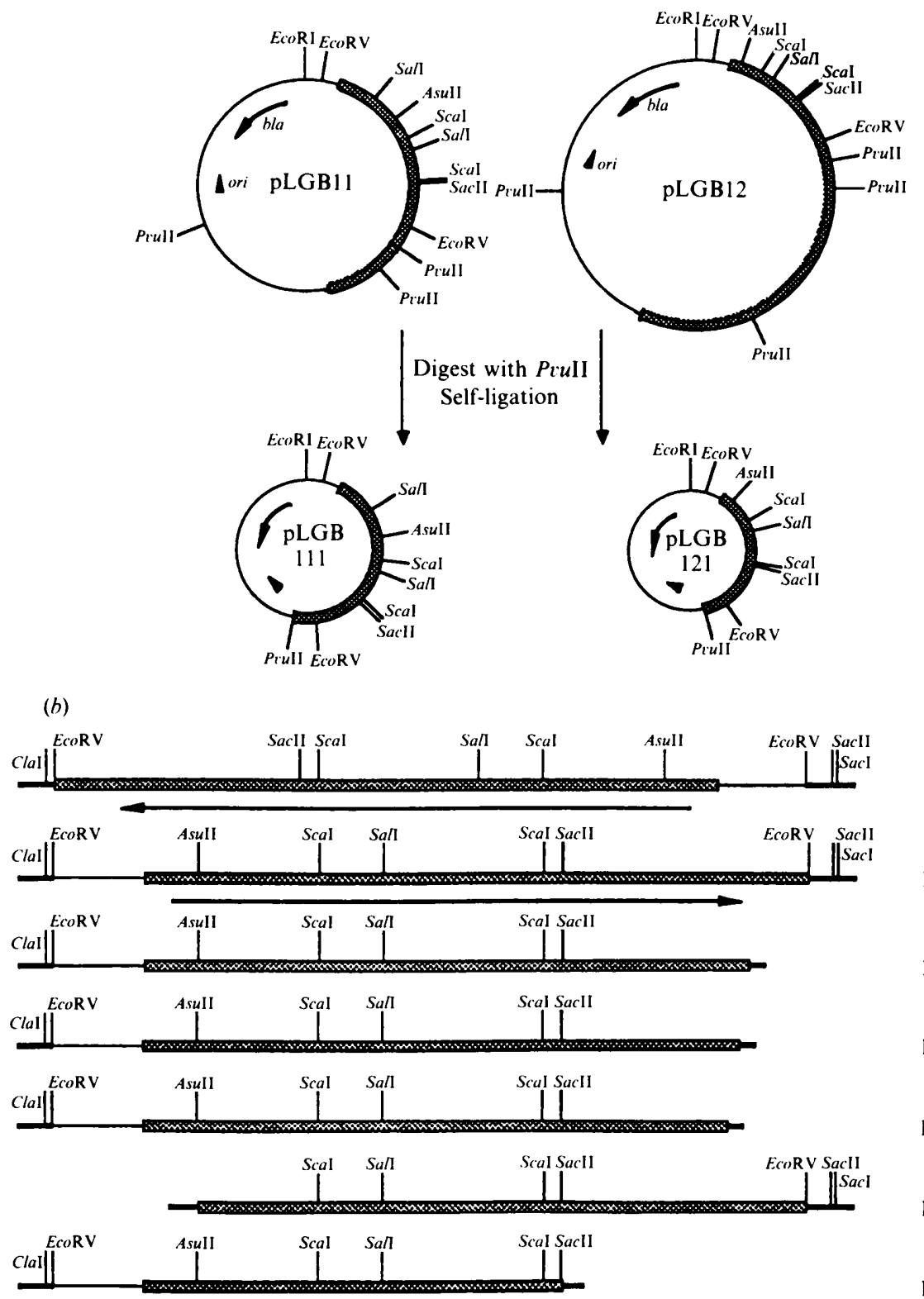

Phenotype

pLGBe

pLGBe274

pLGBe271

pLGBe 320

pLGBeCA

pLGBeSS

100 bp 
1 GTAAAAGCAACCTGGCGGCGGTGGACCAACTGGGCAAGGAGGCGGAAAAGGCCAAGGCGGCAAGCGCTGTC

72 CGTGAAGGTGAAGGCGGTAAGTCTGGGCATGACGGCAAAGGCGCAGGGCAGGGCGCCGGGCATGCCGGTGG

143 GCACTCCGCCAACGGTCATTGATTGATCGCTGACGGGTTCACAAAACCTACAAGGGCTGGAACAATGTCGG

214 CCACTTTCA ATG GTG TTT TTC GAG GCG GCT TAC GTG CAG ATT CAG GGT CAT TAC 1 Met val Phe phe Glu Ala Ala Tyr Val Gln Ile Gln Gly His Tyr AsuII

268 GAA CTC CAG TTC GAA GCG ATA CGT GAA GCG TTT GCC GCG CTG TTC GAT GAC CCA 16 Glu Leu Gln Phe Glu Ala Ile Arg Glu Ala Phe Ala Ala Leu Phe Asp Asp Pro

322 CAG GAG CGT GGC GCC GGG CTT TGC ATT CAG ATC GGC GGC GAA ACC GTG GTC GAT 34. Gln Glu Arg Gly Ala Gly Leu Cys Ile Gln Ile Gly Gly glu thr val Val Asp

376 CTG TGG GCC GGC ACC GCT GAC AAG GAC GGT GCC GAG GCC TGG CAC AGC GAC ACC 52 Leu Trp Ala Giy Thr Ala Asp lys Asp Gly Ala Glu Ala Trp His Ser Asp Thr

430 ATC GTC AAT CTT TTC TCC TGC ACC AAG ACA TTT ACT GCC GTC ACG GCC CTG CAA 70 Ile Val Asn Leu phe Ser Cys Thr Lys Thr phe Thr Ala Val Thr Ala Leu Gln Scal

484 TTG GTG GCT GAG GGT AAg TTG CAG TTG GAC GCT CCA GTT GCC AAG TAC TGG CCG 88 Leu val Ala Glu Gly lys Leu Gin Leu Asp Ala pro Val Ala Lys tyr trp pro

538 GAA TTT GCC GCT GCC GGT AAG GAA AGC ATC ACG CTG CGC CAG TTG CTC TGC CAT 106 Glu phe Ala Ala Ala Gly Lys Glu ser Ile Thr Leu Arg Gln Leu Leu Cys His

592 CAG GCG GGT TTG CCG GCG ATC CGC GAG ATG CTG CCC ACC GAG GCC CTG TAT GAC 124 Gln Ala Gly Leu Pro Ala Ile Arg Glu Met Leu pro Thr Glu Ala Leu tyr Asp Sall

646 TGG CAA CTG ATG GTC GAC ACC CTC GCG GCC GAA GCA CCC TGG TGG ACG CCG GGC 142 Trp Gin Leu Met val Asp Thr Leu Ala Ala Glu Ala Pro Trp trp Thr pro Gly

700 CAA GGC CAT GGT TAC GAG GCG ATC ACC TAC GGC TGG CTG GTC GGC GAA CTG CTG 160 Gln Gly His Gly Tyr Glu Ala Ile Thr Tyr Gly Trp Leu val Gly Glu Leu Leu

754 CGC CGC GCC GAT GGG CGT GGG CCT GGT GAA TCC ATT GTG GCG CGC GTT GCA CGG 178 Arg Arg Ala Asp Gly Arg Gly pro Gly Glu Ser Ile val Ala Arg val Ala Arg

808 CCG TTG GGC CTG GAC TTT CAT GTG GGC CTG GCG GAT GAA GAG TTT TAT CGT GTT 196 pro Leu Gly Leu Asp phe His Val Gly Leu Ala Asp Glu Glu phe tyr Arg Val

862 GCC CAT ATA GCG CGC AGC AAA GGC AAT ATG GGC GAT GAA GCT GCG CAA CGT TTA 2:14 Ala His Ile Ala Arg Ser lys Gly Asn Met Gly Asp Glu Ala Ala gln Arg Leu

916 CTG CAA GTA ATG ATG CGT GAA CCC ACC GCC ATG ACC ACA CGG GCA TTT GCC AAT 232 Leu Gln val Met Met Arg Glu pro Thr Ala Met Thr Thr Arg Ala phe Ala Asn ScaI

970 CCA CCG TCT ATT TTG ACC AGT ACT AAT AAA CCT GAA TGG CGA CGC ATG CAG CAG 250 Pro pro ser Ile Leu Thr Ser Thr Asn Lys pro Glu trp Arg Arg Met Gin Gln SacII

1024 CCC GCG GCT AAT GGT CAC GGT AAT GCG CGT AGC CTG GCG GGT TTT TAT AGT GGT 268 pro ala Ala Asn Gly His Gly Asn Ala Arg Ser leu Ala Gly phe tyr Ser Gly

1078 TTG TTG GAC GGT AGT TTG TTG GAA GCC GAC ATG CTC GAA GAG TTG ACC CGT GAA 286 Leu Leu Asp Gly Ser Leu Leu Glu Ala Asp Met Leu Glu Glu Leu Thr Arg Glu

1132 CAC AGT ATC GGG CCG GAT AAA ACA TTA TTG ACA CAA ACT CGC TTT GGC TTG GGC 304 His Ser Ile Gly Pro Asp Lys Thr Leu Leu Thr Gln Thr arg Phe Gly Leu Gly 2186 TGC ATG TTG GAT CAA CCG CAG ATG CCT AAT GCC ACA TTC GGC CTT GGC CCG CGT 322 Cys Met Leu Asp Gin pro Gln Met pro Asn Ala Thr phe Gly Leu Gly pro Arg

1240 GCT TTT GGG CAT CCT GGT GCA GGT GGA TCG GTA GGT TTT GCC GAC CCC GAA CAC 340 Ala Phe Gly His Pro Gly Ala Gly Gly Ser Val Gly Phe Ala Asp Pro Glu His 


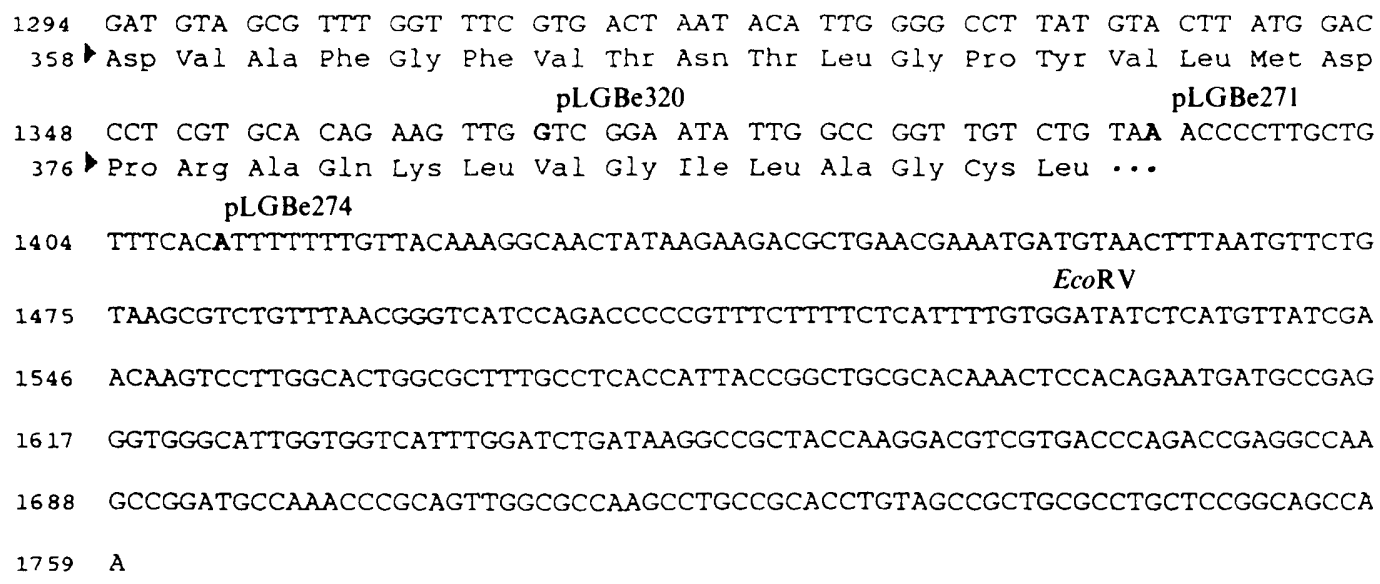

Fig. 2. Nucleotide sequence of the est $A$ coding region. Nucleotide and derived amino acid sequences are numbered on the left. The proposed Shine-Dalgarno sequence (SD) is underlined. Relevant restriction sites are marked above the sequence. Also noted above the sequence are the plasmids containing deletions created by exonuclease III (see also Fig. $1 b$ ) from the EcoRV site into the est $A$ coding region. The deletions extend to, but do not include, the nucleotide residues shown in bold in the nucleotide sequence.

subcloning to define the coding region. Both pLGB11 and pLGB12 were digested with PvuII followed by self ligation. The resulting plasmids, pLGB121 and pLGB111 (see Fig. 1a), both retained activity on TBA. To facilitate sequence determination, an EcoRV fragment from pLGB121 was cloned in both orientations into the EcoRV site of pSK to give pLGBe and pLGBd (see Fig. $1 b$ ). Both orientations gave detectable activity on TBA; however, pLGBd was considerably more active than $\mathrm{pLGBe}$, indicating that a vector promoter may be involved in expression. Since later studies (see below) indicate that the gene product is an esterase, the gene has been designated est $A$.

\section{Nucleotide sequence of the est $A$ region}

The nucleotide sequence of the $e s t A$ gene and its flanking regions was determined entirely on both strands using templates generated by one of three methods: (1) When sequencing regions were not contained within $\mathrm{pLGBe}$ or pLGBd, fragments from pLGB 111 were cloned into M13 vectors; (2) pLGBd and pLGBe were digested with restriction enzymes and self-ligated; or (3) overlapping unidirectional deletions of pLGBe were created using exonuclease III and mungbean nuclease. The nucleotide sequence of the est $A$ coding region is shown in Fig. 2. An ORF encoding a polypeptide of 389 amino acid residues with a calculated molecular mass of $42276 \mathrm{Da}$ initiates with a methionine codon at nucleotide position 224 , and terminates with a TAA codon at nucleotide position 1393. A notably weak Shine-Dalgarno (SD) sequence, comprising only two bases, is present, appropriately spaced, 9 bp upstream from the initiating methionine residue (see Gold et al., 1981). Codon usage analysis of est $A$ (data not shown) reveals a preference for synonymous codons with $\mathrm{C}$ or $\mathrm{G}$ residues in the third position, which is particularly evident in the case of codons for ala, leu and cys. This is consistent with the high genomic $\mathrm{G}+\mathrm{C}$ content in pseudomonads (West \& Iglewski, 1988). Comparison of est $A$ with sequences in GenBank did not reveal any significant similarities at the nucleotide or amino acid levels. Also, no significant similarity is evident between the deduced amino acid sequence of the est $A$ gene product and that of an esterase from an isolate of Pseudomonas fluorescens (Choi et al., 1990).

\section{Definition of the coding region of the est $A$ gene}

Because of the convenient orientation of the polylinker in pLGBe, deletions of this plasmid (initially constructed for sequencing) were used to define the coding region of the est $A$ gene. TGl was transformed with either pLGBe or deletions of pLGBe, plated onto TBA and incubated at $30{ }^{\circ} \mathrm{C}$ for $4-8 \mathrm{~d}$. Activity was scored as a clear halo around individual colonies. The results of these deletions on activity are presented in Fig. $1(b)$. Deletions outside the coding region near the $3^{\prime}$ end of the ORF (pLGBe274 and pLGBe271) do not result in any loss of activity compared to the undeleted plasmid ( $\mathrm{pLGBe}$ ). Cells containing pLGBe 320 are EstA ${ }^{-}$, as are cells containing pLGBeSS, formed by deleting from the SacII site in the ORF to the SacII site in the polylinker. Similarly, a deletion in the $5^{\prime}$ region of the ORF, from AsuII to the ClaI site in the polylinker (to produce pLGBeCA), also results in a total loss of activity. These deletions are 


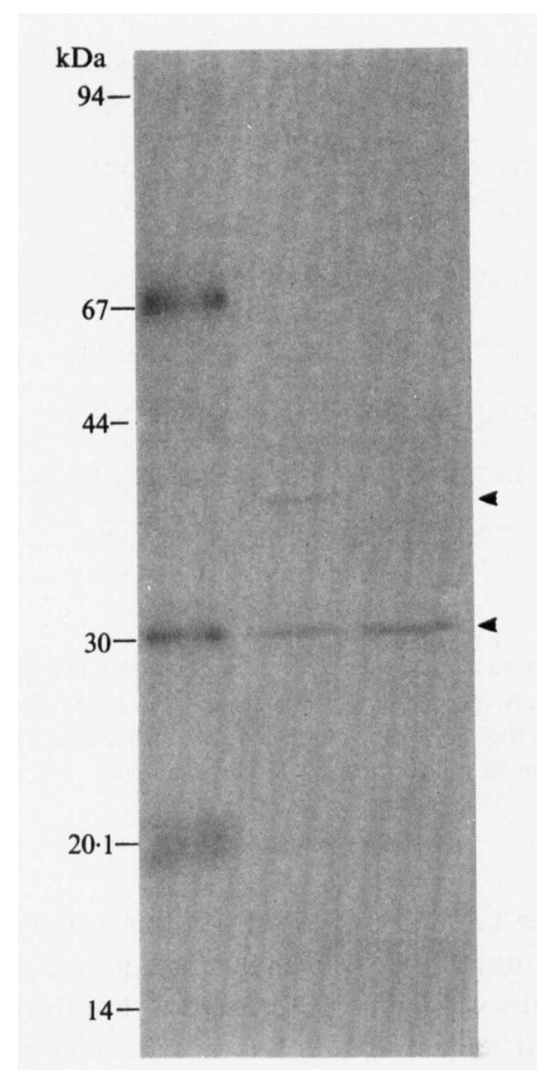

Fig. 3. SDS-PAGE analysis of plasmid-encoded polypeptides labelled by the incorporation of $\left[{ }^{35} \mathrm{~S}\right]$ methionine using maxicells. Samples were electrophoresed through a $12 \%(w / v)$ polyacrylamide gel which was then dried and fluorographed. The exposure time was $20 \mathrm{~h}$. Bars on the left side of the figure represent the position of ${ }^{125}$ I-labelled molecular mass standards. Top arrow indicates the position of the est $A$ gene product, molecular weight $42 \mathrm{kDa}$ (calculated form mobilities of labelled standards). Bottom arrow indicates the position of $\beta$-lactamase, molecular weight $30 \mathrm{kDa}$. Lanes: 1, ${ }^{125} \mathrm{I}$-labelled standards; 2 , extract of maxicells containing pLGBd, containing est $A$ (see Fig. 1b); 3 , extract of maxicells containing a control plasmid (pSK containing an insert of non-bacterial origin)

therefore consistent with the ORF derived from the nucleotide sequencing data.

Further evidence on the identification of the ORF was obtained by selectively labelling plasmid-encoded proteins with $\left[{ }^{35} S\right]$ methionine using the maxicell procedure (Fig. 3). A single polypeptide was observed with a molecular mass of $42 \mathrm{kDa}$, consistent with the molecular mass of $42276 \mathrm{Da}$ calculated from the ORF.

Fig. 4. Effect of solubility on nitrophenol ester hydrolysis by either previously characterized enzyme preparations, or $E$. coli extracts containing estA or lipA. Hydrolysis was measured by nitrophenol release and specific activities were calculated as described in the text. Previously characterized enzyme preparations were suspended in $50 \%$
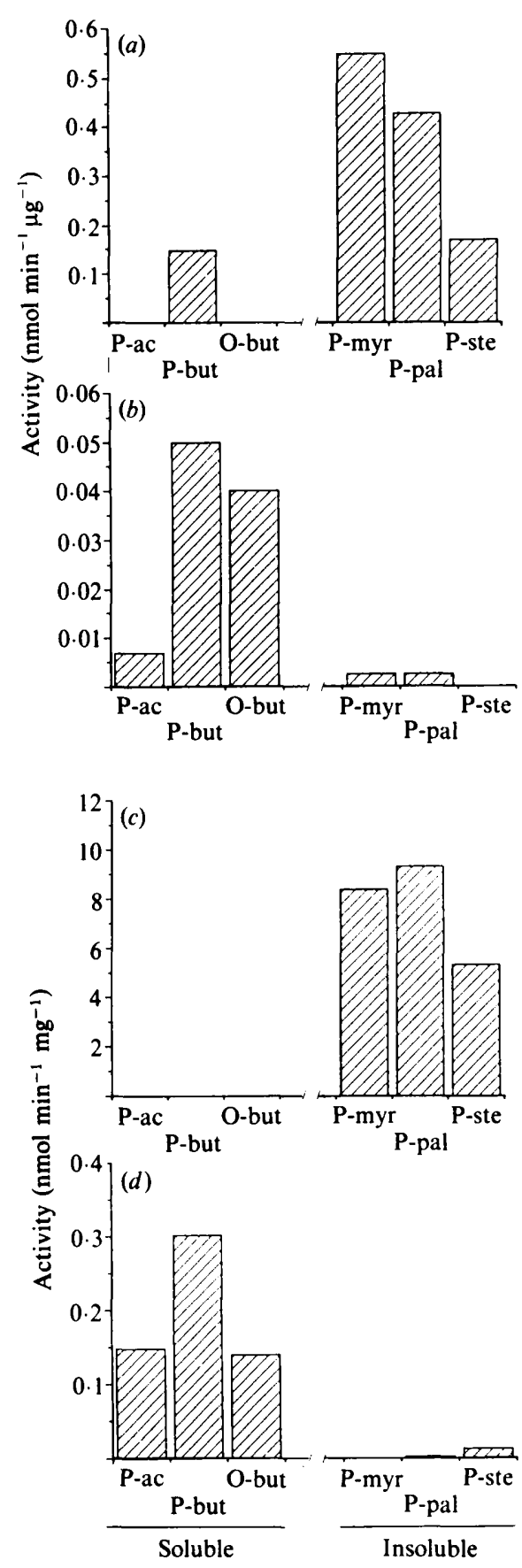

(v/v) glycerol/phosphate buffer, $\mathrm{pH} 7 \cdot 0$, and stored at $-20^{\circ} \mathrm{C}$; cell-free extracts (prepared as described in Methods) were derived from cells grown at $25^{\circ} \mathrm{C}$. (a) Lipase from Pseudomonas sp. (Boehringer), (b) esterase from rabbit liver (Sigma), (c) cell-free extract from $E$. coli (lipA), $(d)$ cell-free extract from $E$. coli (est $A)$. Cell-free extracts from $E$. coli containing a control recombinant plasmid gave a small level of activity in the nitrophenol substrates used (corresponding to between 0.003 and $0.08 \mathrm{nmol} \mathrm{m^{-1 }}\left(\mathrm{mg}^{2}\right.$ protein $\left.{ }^{-1}\right)$ and were subtracted from sample rates. Data are representative of at least three independent experiments, activities are the means of triplicate determinations. Abbreviations: P-ac, p-nitrophenylacetate; P-but, $p$-nitrophenylbutyrate; O-but, $o$-nitrophenylbutyrate; P-myr, $p$-nitrophenylmyristate; P-pal, $p$-nitrophenylpalmitate; P-ste, $p$-nitrophenylstearate. 


\section{Characterization of the est $A$ gene product}

In this investigation, $1 \%(\mathrm{v} / \mathrm{v})$ tributyrin plates were used to screen for enzymes that may be responsible for the production of short-chain fatty acids which cause rancidity in milk. Since tributyrin is partially soluble $(0.01 \%$; Brockerhoff, 1969) in water, the enzyme responsible for clearing tributyrin in solid media (see Methods) could be either an esterase (acting on the soluble component of the substrate) or a lipase (acting on the insoluble portion). To further characterise the est $A$ gene product, cells containing pLGBd were grown on media containing $0.1 \%$ triolein (a completely insoluble compound) together with cells containing a plasmid which contains a gene $(\operatorname{lip} A)$ which encodes a lipase (unpublished results) derived from the same cosmid library as pLGBd. Only those cells containing lip $A$ gave noticeable clearance of triolein after $3-4 \mathrm{~d}$ at $30^{\circ} \mathrm{C}$ (data not presented). Since the lip $A$ gene product was able to act on an insoluble substrate, the enzyme responsible can therefore be identified as a lipase. However, the inability of the est $A$ gene product to hydrolyse triolein may be due to reasons other than the solubility of the substrate. We have therefore compared the activity in cell-free extracts using soluble and insoluble substrates. For comparison, we have also examined a previously characterized esterase and lipase, obtained from commercial sources. Fig. 4(a) shows that water-insoluble compounds ( $p$-nitrophenylmyristate, $p$-nitrophenylpalmitate and $p$-nitrophenylstearate) are all substrates for a lipase derived from a species of Pseudomonas, whereas only one water-soluble compound ( $p$-nitrophenylbutyrate) is a substrate for this enzyme; this result is consistent with the enzyme being a lipase, since other lipases have been shown to hydrolyse a few water-miscible esters (Brockerhoff, 1969). In contrast, esterase from rabbit liver only gave significant rates of hydrolysis with the watersoluble substrates $p$-nitrophenylbutyrate and $o$-nitrophenylbutyrate (Fig. $4 b$ ). Consistent with observations that cells containing lipA can hydrolyse triolein (a waterinsoluble substrate), Fig. 4(c) shows that extracts of cells containing $\operatorname{lip} A$ hydrolyse the water-insoluble esters of nitrophenol in preference to the water-soluble substrates. In marked contrast, extracts of cells containing est $A$ only gave significant rates of hydrolysis with the watersoluble substrates ( $p$-nitrophenylbutyrate, $p$-nitrophenylacetate and $o$-nitrophenylbutyrate), and not with the insoluble substrates; this result suggests that the est $A$ gene codes for an esterase (Fig. 4c).

The characterization of est $A$ will allow a determination of its possible role in the generation of fatty acids from milk triglycerides. For example, est $A$ mutants of Pseudomonas LS107d2 may be constructed by site- directed mutagenesis using the cloned gene. Also, studies on the specificity of the est $A$ gene-product will be aided by expression in $E$. coli.

\section{References}

BROCKERHOFF, H. (1969). Action of pancreatic lipase on emulsions of water-soluble esters. Archives of Biochemistry and Biophysics 134, 366-371.

Calhoun, D. H. \& Gray, J. E. (1981). Detection of proteins coded by cloned DNA segments. Focus (BRL) $31,10-11$.

Chol, K. D., Ho Jeohn, G., RheE, J. S. \& YoO, O. J. (1990). Cloning and nucleotide sequence of an esterase gene from Pseudomonas fluorescens and expression of the gene in Escherichia coli. Agricultural and Biological Chemistry 54, 2039-2045.

Cousin, M. A. (1982). Presence and activity of psychrotrophic microorganisms in milk and dairy products: a review. Journal of Food Protection 45, 172-207.

Cousin, M. A. (1989). Physical and biochemical effects on milk components. In Enzymes of Psychrotrophs in Raw Food, pp. 121-152. Edited by R. C. McKellar. Boca Raton, Florida: CRC Press.

Cox, J. \& MACRAE, I. C. (1989). A numerical taxonomic study of proteolytic and lipolytic psychrotrophs from caprine milk. Journal of Applied Bacteriology 66, 137-152.

Dagert, M. \& Ehrlich, S. D. (1979). Prolonged incubation in calcium chloride improves the competence of $E$. coli cells. Gene 6, 23-28.

DeETH, H. C. \& Fitzgerald, C. H. (1983). Lipolytic enzymes and hydrolytic rancidity in milk and milk products. In Dairy Chemistry-2: Lipids, pp. 195-239. Edited by P. F. Fox. Barking: Applied Science Publishers.

Gold, L., Pribnow, D., Schneider, T., Shneidling, S., Singer, B. S. \& STormo, G. (1981). Translational initiation in procaryotes. Annual Review of Microbiology 35, 365-403.

Griffiths, M. W., Phillips, J. D. \& Muir, D. D. (1981). Thermostability of proteinases and lipases from a number of species of psychrotrophic bacteria of dairy origin. Journal of Applied Bacteriology 50, 289-303.

HENIKOFF, S. (1984). Unidirectional digestion with exonuclease III creates targeted breakpoints for DNA sequencing. Gene 28, 351-359.

HoHN, B. \& Collins, J. (1980). A small cosmid for efficient cloning of large DNA fragments. Gene 11, 291-298.

Kraft, R., TARdiff, J., Krauter, K. S. \& Leinwand, L. A. (1988). Using mini-prep plasmid DNA for sequencing double stranded templates with sequenase ${ }^{\mathrm{TM}}$. Biotechniques 6, 544-546.

LIM, H. M. \& PENN, J. J. (1988). Optimal conditions for supercoil DNA sequencing with the Escherichia coli DNA polymerase 1 large fragment. Gene Analysis Techniques 5, 32-39.

Messing, J. (1983). New M13 vectors for cloning. Methods in Enzymology 101, 20-78.

Muir, D. D., Phillips, J. D. \& Dalgleish, D. G. (1979). The lipolytic and proteolytic activity of bacteria isolated from blended raw milk. Journal of the Society of Dairy Technology 32, 19-23.

Olsson, A., Moks, T., Uhlen, M. \& GAAL, A. B. (1984). Uniformly spaced banding pattern in DNA sequencing gels by use of fieldstrength gradient. Journal of Biochemical and Biophysical Methods 10, 83-90.

Prenki, P. \& KRISCH, H. M. (1982). A modified pBR322 vector with improved properties for the cloning, recovery and sequencing of blunt-ended DNA fragments. Gene 17, 189-196.

Rowe, M. \& Gilmour, A. (1985). The present and future importance of psychrotrophic bacteria. Dairy Industries International 50, 14-19.

SAMBroOK, J., Fritsch, E. F. \& Maniatis, T. (1989). Molecular Cloning: a Laboratory Manual. Cold Spring Harbor, NY: Cold Spring Harbor Laboratory Press.

Shelley, A. W., Deeth, H. C. \& MacRae, I. C. (1986). Growth of lipolytic psychrotrophic pseudomonads in raw and ultra-heat-treated milk. Journal of Applied Bacteriology 61, 395-400. 
Shelley, A. W., Deeth, H. C. \& MacRae, I. C. (1987). A numerical taxonomic study of psychrotrophic bacteria associated with lipolytic storage of raw milk. Journal of Applied Bacteriology 62, 197-207.

SuHReN, G. (1989). Producer microorganisms. In Enzymes of Psychrotrophs in Raw Food, pp. 3-34. Edited by R. C. McKellar. Boca Raton, Florida: CRC Press.

TARBOR, S. \& RICHARDSON, C. C. (1985). A bacteriophage T7 RNA polymerase/promoter system for controlled exclusive expression of specific genes. Proceedings of the National Academy of Sciences of the United States of America 84, 4767-4771.
TARBOR, S. \& RICHARDSON, C. C. (1987). DNA sequence analysis with a modified bacteriophage T7 DNA polymerase. Proceedings of the National Academy of Sciences of the United States of America 84, 4767-4771.

West, S. E. H. \& IgLEwSKI, B. H. (1988). Codon usage in Pseudomonas aeruginosa. Nucleic Acids Research 16, 9323-9335.

WINKLER, U. K. \& StUCKMANN, M. (1979). Glycogen, hyaluronate, and some other polysaccharides greatly enhance the formation of exolipase by Serratia marcescens. Journal of Bacteriology 138, 663-670. 